\title{
The effects of press and pulse disturbance by long and short-term pollution on the fish community in the Sinos River, RS, Brazil
}

\author{
Schulz, UH. ${ }^{a *}$ and Costa, $P F^{b}$ \\ a'Laboratório de Ecologia de Peixes/C2, Universidade do Vale do Rio dos Sinos - UNISINOS, \\ CEP 93022-000, São Leopoldo, RS, Brazil \\ bBiota Soluções Ambientais, Rua Lindolfo Collor, 439, CEP 93022-000, São Leopoldo, RS, Brazil \\ *e-mail: uwe@unisinos.br
}

Received: May 24, 2013 - Accepted: November 13, 2013 - Distributed: May 31, 2015

(With 4 figures)

\begin{abstract}
The fish fauna of the Sinos River has been subjected to severe pollution since the 1970's. Continuous discharges of industrial and municipal sewage cause hypoxia and often even fish kills. The objectives of the present study are to assess long-term effects of pollution on the fish community over a time scale of approximately ten years and to investigate recuperation of the fish fauna after a massive fish kill in 2006. To assess the long-term impacts, seasonal sampling was conducted from September 2007 to March 2009 in four sites which were investigated in 1998/99 with the same methodology. The effects of the fish kill were investigated by comparing the present fauna in the affected river stretch with the fauna of an unaffected adjacent river stretch. The collective community properties richness and Shannon diversity changed during the ten year interval in a consistent pattern. Richness and Shannon diversity increased significantly in all sites, abundance values, however, did not. Analysis of species constancy and cluster analysis showed that the differences between the 1998/99 and 2007/09 studies were relatively small. The comparison of the reaches affected by the 2006 fish kills showed a rapid recovery within one year. Probably the Sinos fish fauna suffered the most severe impacts in the 70s of the last century, which could not be documented by this study. After an initial decline, the community displays relatively stable patterns with a tendency of recovery. After a severe fish kill, faunal recovery was rapid, probably favoured by the proximity of unpolluted source areas and physical habitat integrity of the Sinos River.
\end{abstract}

Keywords: sewage, fish kill, community stability, resilience.

\section{Efeitos de distúrbios contínuos e pulsados da poluição aguda e de longo prazo sobre a comunidade de peixes no Rio dos Sinos, RS, Brasil}

\section{Resumo}

A fauna de peixes do Rio dos Sinos vem sendo exposta a uma poluição grave desde os anos 70 do século passado. Descargas contínuas de esgotos industriais e urbanos causaram hipóxia e recorrentes mortandades de peixes. Os objetivos do presente estudo são: avaliar os efeitos de longo prazo da poluição sobre a comunidade de peixes e investigar a recuperação da ictiofauna após uma mortandade severa em 2006. Para avaliar os impactos de longo prazo, foram realizados amostragens sazonais entre setembro de 2007 a março de 2009 em quatro locais que foram investigados em 1998/99 com a mesma metodologia. Os efeitos da mortandade de peixes foram investigados comparando a fauna no trecho afetado pela mortandade com o que não foi afetado. As propriedades coletivas da comunidade íctica riqueza e diversidade de Shannon aumentaram durante o intervalo de 10 anos em todos os pontos de amostragem, porém os valores da abundância ficaram estáveis. A análise da constância das espécies e a análise de agrupamento mostraram que as diferenças encontradas entre os estudos 1998-1999 e 2007/09 são pouco expressivas. A comparação dos trechos afetados e não afetados pela mortandade de peixes mostrou uma rápida recuperação da fauna que ocorreu em um ano. A ictiofauna do Rio dos Sinos sofreu provavelmente os impactos mais graves nos anos 70 do século passado, contudo, não documentado por este estudo. Depois de um declínio inicial a comunidade exibiu padrões relativamente estáveis com tendências de recuperação. Após as mortandades de 2006 a recuperação da fauna foi rápida, provavelmente favorecida pela proximidade de áreas de fonte não poluídas e pela integridade física dos habitats do Rio dos Sinos.

Palavras-chave: esgoto, mortalidade de peixes, estabilidade da comunidade, resiliência. 


\section{Introduction}

The Sinos River, in Brazil's southernmost state, Rio Grande do Sul, has received large quantities of domestic and industrial sewage since the 1970's (Rio Grande do Sul, 1999). Monitoring conducted by the State Department of Environmental Protection between 1990 and 2010 shows that only the headwaters are still in good condition. Mean dissolved oxygen concentrations are above $7.0 \mathrm{mg} / \mathrm{L}$. The water quality is Class I, which is the second best in the Brazilian ranking system. Water quality gradually decreases to Class III in agricultural areas of the upper floodplain section. However, downriver sections in urban areas are Class IV, which is the worst in the Brazilian ranking system, with mean annual oxygen concentrations lower than $3.0 \mathrm{mg} / \mathrm{L}$ in some years (Rio Grande do Sul, 2013).

In the Sinos River basin water quality degradation is related to the discharge of large amounts of organic and industrial sewage. Only one municipality out of 32 operates sewage treatment plants. Urban streams were converted into sewage ditches. During Stream Walk Surveys, organised by the local water committee Comitesinos, 2,697 pipes discharging untreated sewage were recorded (Schulz et al., 2006). As a result, fecal coliform counts exceed frequently $10^{5} / \mathrm{L}$ and may reach almost $2 * 10^{5} / \mathrm{L}$ in some cases (Blume et al., 2010; Rio Grande do Sul, 2013).

In addition to organic discharges, industrial effluents contribute to water quality decrease. The Sinos River basin is a national centre of leather processing industries, including tanneries and shoe production facilities (Figueiredo et al., 2010). Additionally metallurgic factories are concentrated in the urban areas. All of them use heavy metals in the production process. Chromium, copper and nickel occur in more than $50 \%$ of all analyses in concentrations attributed to water quality class four (Rio Grande do Sul, 2013). In the decade of the 1970s uncontrolled industrial discharges reached the maximum. From the 1980's onwards, occasional discharges continued, but the industrial sector was more efficiently controlled by the state's environmental agency. Bender et al. (1984) consider these long-term impacts of sewage press disturbances. They occur in periods which are longer than the life span of the longest-lived species of the community.

Sublethal concentrations of pollutants have been shown to weaken fish by immunodepression (Sövényi and Szakolczai, 1993). This process may lead to a higher susceptibility to attack by pathogens (Austin, 1998). Large amounts of organic sewage induce hypoxia and even anoxia, particularly during summer with high water temperatures. Prolonged hypoxia may change species composition and decrease species richness (Diaz and Rosenberg, 1995). In the long term, a shift from K to r selected species may be observed (Pihl et al., 1991). Enduring low oxygen concentrations may reduce growth and reproduction success (Schulz and Martins-Junior, 2001; Karim et al., 2003). In this context, fish species richness is known to be a sensitive indicator of the condition and degradation of rivers and lakes since the decrease in the number of fish species is clearly confirmed in locations where aquatic pollution is high (Magurran and Phillip, 2001; Barrella and Petrere, 2003).

In the Sinos River, small scale fish kills are frequent, particularly during summer with high temperatures and low water flow, conditions which favour hypoxia. Statistics on these events do not exist since they are not always reported to environmental agencies. Additionally large scale fish kills occur, as the two events in October 2006 (Naime and Fagundes, 2005). On $6^{\text {th }}$ of October 2006, moribund or dead fish were detected at the mouth of the Portão River, one of the most polluted tributaries of the Sinos in the lowland section. During the following two days an estimated quantity of $100 \mathrm{t}$ fish died. The cause of this fish kill was never determined, but moribund fish did not display typical symptoms of hypoxia. The intensity and the dynamics of the event indicated the discharge of a highly toxic substance of unknown origin. In the same month, a second fish kill occurred in the same river section. The latter clearly was the consequence of enduring hypoxia, with moribund fish swimming at the surface in an attempt to breathe atmospheric oxygen (Rio Grande do Sul, 2007). Both fish kill episodes may be considered pulse disturbances (Bender et al., 1984). Pulse disturbances are discrete events, shorter than the maximum life span of the longest lived species of the affected community, and are typically caused by point source inputs or short and intense hydrologic events like flash floods.

The present study has two objectives. First we compared the collective fish community properties richness, abundance and Shannon diversity at four sites collected in 2007/09 with collections made at the same sites in 1998/99 to test the hypothesis that press disturbance of long-term pollution induces changes of these parameters. Second we compared the fish fauna of the river stretch affected by the 2006 fish kills with the adjacent unaffected upstream river stretch to test if the community recovered from the effect of the pulse disturbance.

\section{Material and Methods}

\subsection{Study area}

The original vegetation in the watershed is deciduous seasonal forest and, according to the Köppen classification, the predominant climate in the region is subtropical humid with precipitation throughout the year (Moreno, 1961).

From the mouth of the Paranhana River, the Sinos is a seventh order river. The total extension is $190 \mathrm{~km}$. The drainage area is approximately $3.800 \mathrm{~km}^{2}$ (Figueiredo et al., 2010). The headwaters are located at $700 \mathrm{~m}$ above sea level (a.s.1.) in the Serra Geral highlands, and its mouth is at $10 \mathrm{~m}$ a.s.l. in the Jacuí Delta, close to the state capital, Porto Alegre. The most important tributaries are the Rolante, Ilha and Paranhana Rivers (Petry and Schulz, 2006).

The headwaters are characterised by steep slopes and an entrenched stream bed with two waterfalls $(>25 \mathrm{~m})$ within the first $5 \mathrm{~km}$, and a riffle-pool-run structure between the sampling sites Fraga (P1) and Caraá (P2; Figure 1). This section has a low impact level. The Sinos above 

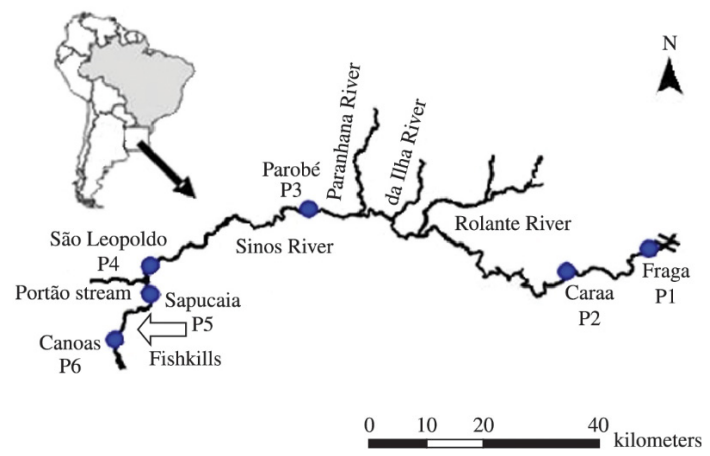

Figure 1. Sampling sites along the Sinos River. Sites P1 to P4 were sampled in 1998/99 and 2007/09 and used to investigate long-term effects. Sites P5 and P6 were affected by the 2006 fish kills and compared to adjacent unaffected P4 and P3; Sites P1 and P2 are headwater sites, all other are lowland sites. The lowland section begins $10 \mathrm{~km}$ downstream of P2. // above Fraga indicate two upstream waterfalls.

Fraga is water quality Class I (Brasil, 2005), and below Fraga, quality Class II (Rio Grande Sul, 1999), with small quantities of domestic and agricultural effluents (Petry and Schulz, 2006). When the Sinos River enters the floodplain, water quality decreases to Class III. From the confluence with the Paranhana River Class IV persists until the Sinos River mouth. In this lowland section, the river meanders in the low gradient floodplain, which gradually becomes more urbanised along the longitudinal gradient (Petry and Schulz, 2001). The sites Parobé (P3), São Leopoldo (P4), Sapucaia (P5) and Canoas (P6) are located in the lowland section.

\subsection{Sampling process}

Each of the six sites was sampled four times (seasonally) from September 2007 to March 2009. The sites from Fraga (P1) to São Leopoldo (P4) were used to investigate the long-term changes of the fish fauna, comparing the community of the $2007 / 09$ collection with the community sampled in 1998/99, at the same sites and with the same methodology. Sample sites Sapucaia (P5) and Canoas (P6) were affected by the 2006 fish kills. They were compared to the adjacent not affected upstream sections, represented by the sites São Leopoldo (P4) and Parobé (P3).

In the present study, the sampling procedures of the 1998/99 study (Petry and Schulz, 2006) were replicated. Sampling consisted of a set of seven gill nets with mesh size ranging from 15 to $50 \mathrm{~mm}(15,20,25,30,35,40$ and 50 ) between adjacent knots and electrofishing along the margins of the Sinos River for 50 minutes. The nets remained set during 16 hours, from $16.00 \mathrm{~h}$ to $08.00 \mathrm{~h}$ of the following day. One pass electrofishing was conducted along the margins of each location using an aluminum boat and a model FEG 800 generator (EFKO, Leutkirch Germany) with $7.5 \mathrm{~kW}$ and 750 volts unpulsed direct current. The extension of the sampled river stretch was about $200 \mathrm{~m}$ at each site.

The captured individuals were anesthetised in $50 \mathrm{mgL}^{-1}$ clove oil and fixed on-site in 10\% formalin. After at least one week they were transferred into $70 \%$ ethanol at the Unisinos Fish Ecology Laboratory.

\subsection{Data analysis}

The long-term effects of press disturbance effects on the fish community and the recovery of the sites affected by the pulse disturbance of the 2006 fish kills were assessed by comparing rarefied species richness, total abundance (number of individuals in gill nets + number of individuals captured by electrofishing) and Shannon diversity. To estimate long-term effects of press disturbance the captures at the sites that were sampled in 1999/99 (Fraga P1, Caraá P2, Parobé P3 and São Leopoldo P4) were compared to the captures at the same sites in 2007/2009. Mean rarefied richness (Krebs, 1998), abundance, and Shannon diversity of the seasonal samples of the 1998/99 samples were compared to the mean rarefied richness, abundance, and Shannon diversity of the seasonal $2007 / 09$ samples by bifactorial ANOVA to test the effects of longitudinal distribution of the sampling sites and sampling periods. When significant effects were detected post hoc Bonferroni test was applied. All variables met the criterions of normality and homogeneity of variances without transformations.

For each site from P1 to P4 we also compared the species' rank abundances between the1998/99 and the 2007/09 samples by using the Spearman's coefficient of rank correlation for all species with a relative abundance $>2 \%$. Lower abundances were not included to cut off possible spurious correlations due to the influence of rare species (Meffe and Sheldon, 1990).

Additionally Bray-Curtis similarity between the fish fauna in the 1998/99 and the present 2007/09 study was compared by the hierarchical cluster analysis (Pinto-Coelho, 2000). The index is based on composition as a function of species abundance.

The effect of pulse disturbance was estimated by pooling the seasonal captures of the sampling sites Canoas (P6) with Sapucaia (P5), which were affected by the 2006 kills. Mean rarefied richness, abundance and Shannon diversity of these sites were compared by Student-t test to the pooled captures of São Leopoldo (P5) and Parobé (P4). The latter sites were unaffected by the 2006 fish kills.

Shannon biodiversity and rarefied richness were calculated by using the PAST software (Hammer et al., 2003). Bifactorial ANOVA and Student-t test were run by SPSS vers. 21 (IBM, 2012).

\section{Results}

At the six sampling sites in this 2007/09 study, a total of 8,481 individuals of seven orders, 21 families and 68 species were collected. The most abundant species were Astyanax fasciatus (Cuvier, 1819) (19.1\%), Hyphessobrycon luetkenii (Boulenger, 1887) (10.8\%), Cyphocharax voga (Hensel, 1870) (9.9\%) and Astyanax jacuhiensis (Cope, 1894) 
(8.87\%). The dominant orders were Characiformes (35\%) and Siluriformes (30\%) and the families with the greatest species richness were Characidae (26.5\%), Loricariidae (19.2\%) and Cichlidae (13.3\%).

At the sites P1 to P4 4,600 individuals were captured during the 2007/09 study. At these sites, a total of six orders, 19 families and 63 species were identified. In the 1998/99 study, Petry and Schulz (2006) registered a total of 4,143 individuals belonging to six orders, 20 families and 58 species.

Bifactorial ANOVA showed significant effects of sampling sites on mean rarefied richness $\left(\mathrm{F}_{3,24}=8.475, \mathrm{p}=0.001\right)$ along the longitudinal gradient from the headwaters at Fraga to the lowland site São Leopoldo (Figure 2). In both investigation periods, rarefied richness was highest in Caraá, near the headwater-lowland transition. The effect of sampling periods also was significant $\left(F_{1,24}=7.638 ; p=0.011\right)$. During the 2007/09 study mean richness values increased at all sites (Figure 2; Table 1). However, both effects were independent, no interaction of the variables sampling sites and sampling period was observed $\left(\mathrm{F}_{3,24}=0.189 ; \mathrm{p}=0.903\right)$. Pos hoc Bonferroni tests indicated significant differences between Fraga and Caraá ( $\mathrm{p}=0.003)$, Fraga and Parobé $(\mathrm{p}=0.024)$, Caraá and São Leopoldo and Parobé and São Leopoldo $(\mathrm{p}=0.045)$. Figure 2 shows that the distribution pattern of rarefied richness along the longitudinal gradient was similar in both investigation periods. Sampling sites $\left(\mathrm{F}_{3,24}=0.754\right.$; $\mathrm{p}=0.531)$ and sampling period $\left(\mathrm{F}_{1,24}=0.49 ; \mathrm{p}=0.656\right)$ had no significant effect on abundance. The effect of sampling sites $\left(\mathrm{F}_{3,24}=6.722 ; \mathrm{p}=0.002\right)$ and sampling period $\left(\mathrm{F}_{1,24}=4.204 ; \mathrm{p}=0.051\right)$ on Shannon diversity was similar to rarefied richness. Both effects were independent from each other $\left(\mathrm{F}_{3,24}=0.909 ; \mathrm{p}=0.451\right)$. The post hoc Bonferroni test showed significant differences between Caraá and São Leopoldo $(\mathrm{p}=0.001)$ and between Parobé and São Leopoldo $(\mathrm{p}=0.05)$.

Species rank correlations were significant for all headwater sites (Fraga $\mathrm{p}<0.001$; P1; Caraá $\mathrm{p}<0.001$; P2) and for Parobé $(\mathrm{p}=0.002 ; \mathrm{P} 3)$. Only at São Leopoldo the species rank correlation was not significant $(\mathrm{p}=0.709)$. The coefficient of determination $\mathrm{R}^{2}$ was considerably higher at the headwater sites (Figure 3).

The similarity dendrogram showed the formation of two large clusters with $32 \%$ similarity between the fish community compositions (Figure 4). One group was represented by headwater site Fraga (P1) in both studies and had a similarity of $75 \%$ among the groups and $68 \%$ with Caraá (P2) of the 2007/09 study. In the other group, floodplain site Parobé (P3) had a similarity composition of $61 \%$ between the two studies and was $59.2 \%$ similar with São Leopoldo (P4) in both studies. The composition at $\mathrm{P} 4$ was $59.5 \%$ similar between the two studies.

The effect of pulse disturbance was assessed by comparing fish community parameters of the sites Canoas (P6) and Sapucaia (P5), which were affected by the 2006 fish kills, with São Leopoldo (P4) and Parobé (P3). Mean rarefied richness, Shannon diversity and abundance did
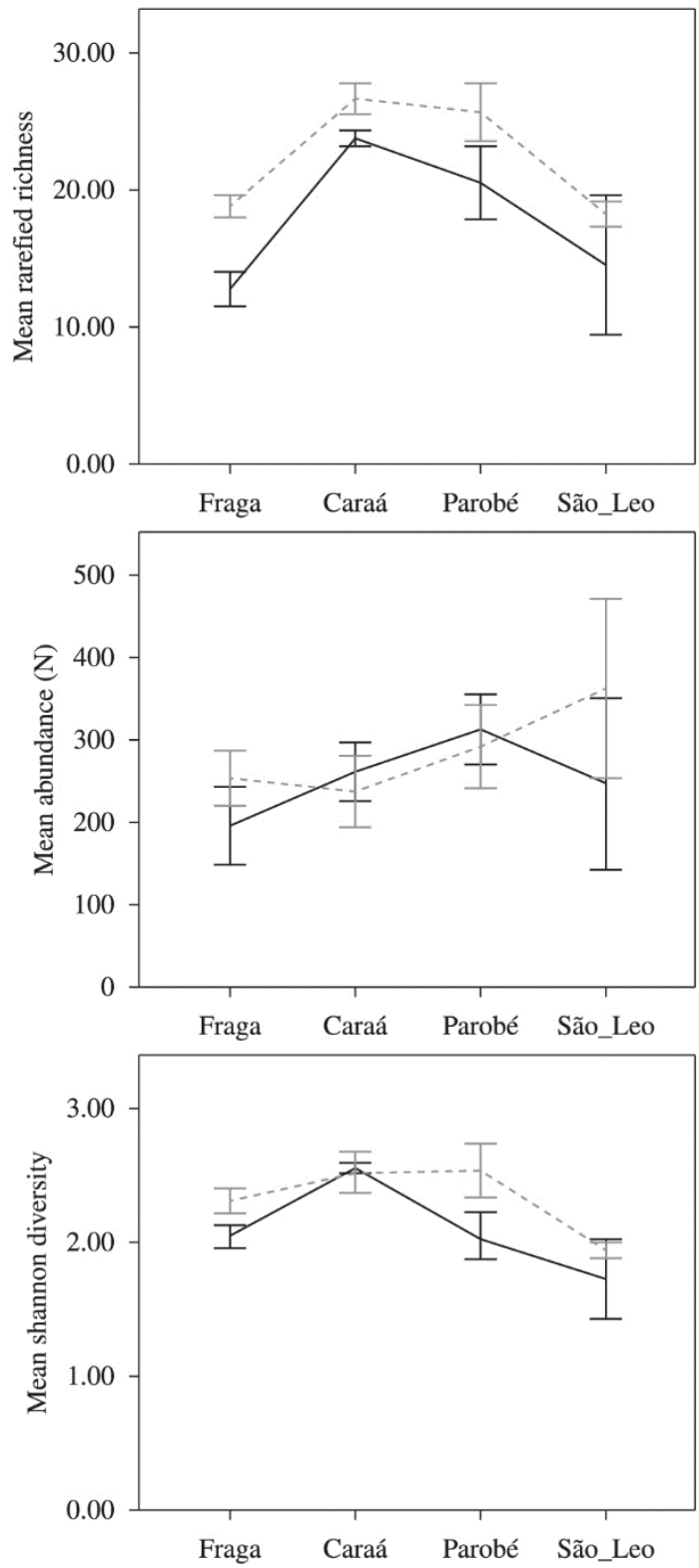

Figure 2. Mean rarefied species richness, abundance and Shannon diversity along the longitudinal gradient, as tested by bifactorial ANOVA. (Solid black line: 1998/99 collection; dashed grey line: 2007/09 collection; bars are standard errors).

not differ significantly between the sites, although mean abundance was considerably higher in the affected river stretch (Table 2).

\section{Discussion}

The comparison of rarefied species richness, total abundance and Shannon index of diversity did not reveal a clear tendency of press disturbance on these collective community properties during the 10-year time span 

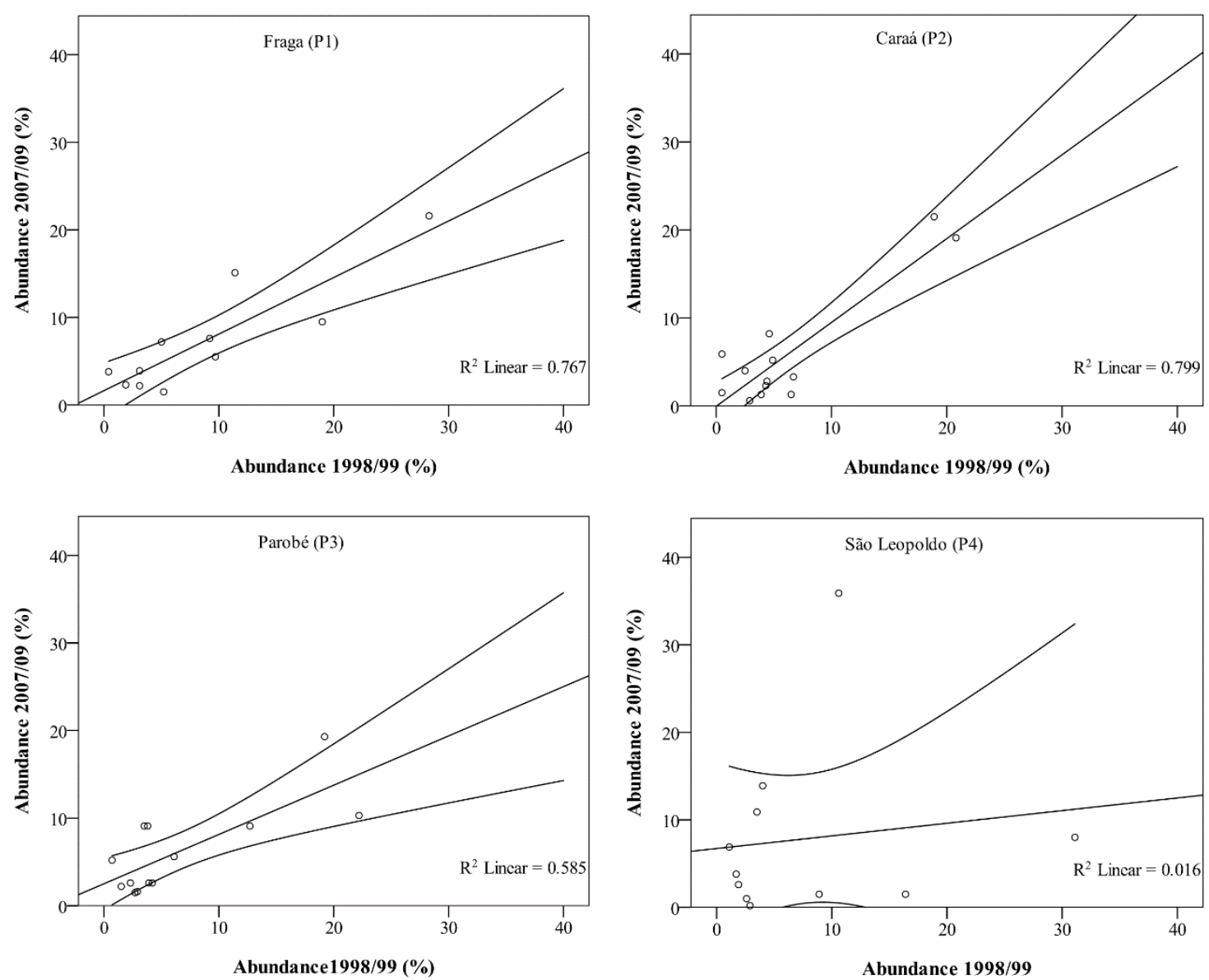

Figure 3. Spearman's rank correlation of species constancy in the $1998 / 99$ and $2007 / 09$ collections with $95 \%$ confidence interval.
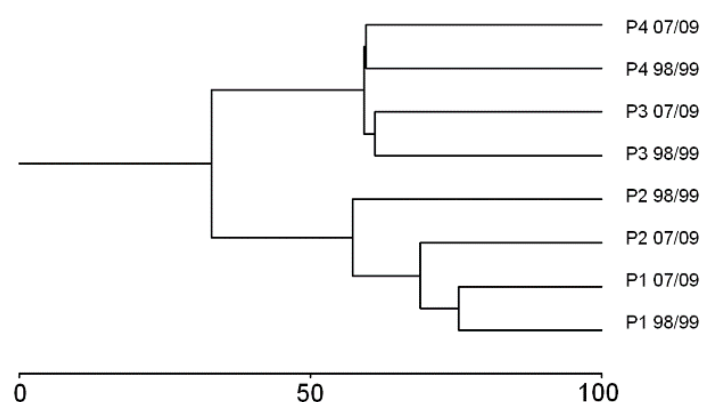

Figure 4. Bray-Curtis similarity of the studies 1998/1999 and 2007/09. P1=Fraga, P2=Caraá, P3=Parobé and P4=São Leopoldo.

between the 1998/99 and the 2007/9 collections. Richness increased in all sites by approximately the same amount and mean Shannon diversity values followed this tendency. An increase in species richness can be a community response to decreasing impact levels (Soto-Galera et al., 1998; Lima-Junior et al, 2006). However, increasing impact levels which occur when an aquatic system shifts from almost pristine to very moderately impacted, may also increase species richness due to slightly higher nutrient input and, consequently, higher primary and secondary production (Mackey and Currie, 2000). This might have been the case in the headwaters. The increase of the trophic state may reduce intra- and interspecific competition, which, consequently, may increase species richness (Clarke and Warwick, 1994). During the ten-year interval that passed between the two studies, the former almost pristine headwaters received slightly increased nutrient loads due to some few new residential constructions, which probably discharge the outflow of the septic tanks indirectly into the river. The reason for richness increase in the lowland section remains mostly unexplained. It may indicate that the Sinos fish community is recovering, even under continuing press disturbance caused by frequent hypoxic conditions.

The effects of sample sites and sample period on abundance was not significant. The effect of sampling sites and investigation period on Shannon diversity was similar to rarefied richness. The headwater site Caraá displayed the highest values, the São Leopoldo the lowest. In general terms it seems that despite the long-term press disturbance by pollution the Sinos River still maintains 
Table 1. Means and standard deviations of rarefied species richness, abundance and Shannon diversity of the 1998/99 and 2007/08 collections at sampling sites Fraga, Caraá, Parobé and São Leopoldo. Unrarefied richness values are given for additional information.

\begin{tabular}{cccccc}
\hline & & Fraga & Caraá & Parobé & São_Leo \\
\hline Rarefied & $1998 / 99$ & $12.8(2.5)$ & $23.8(1.3)$ & $20.5(5.3)$ & $14.5(10.2)$ \\
Richness & $2007 / 09$ & $18.8(1.8)$ & $26.6(2.2)$ & $25.7(4.3)$ & $18.3(1.9)$ \\
& & & & & \\
Richness & $1998 / 99$ & $12.8(2.5)$ & $23.8(1.3)$ & $20.5(5.3)$ & $14.5(10.2)$ \\
& $2007 / 09$ & $19.8(2.2)$ & $29.0(3.7)$ & $29.0(3.2)$ & $22.5(5.4)$ \\
Abundance & $1998 / 99$ & $195.3(97.2)$ & $260.5(70.3)$ & $312.8(85.3)$ & $245.5(209.2)$ \\
& $2007 / 09$ & $253.0(66.7)$ & $235.8(87.4)$ & $292.0(99.1)$ & $361.8(217.8)$ \\
Shannon & $1998 / 99$ & $2.1(0.17)$ & $2.6(0.08)$ & $2.1(0.35)$ & $1.7(0.59)$ \\
Diversity & $2007 / 09$ & $2.3(0.19)$ & $2.5(0.31)$ & $2.5(0.40)$ & $1.9(0.12)$ \\
\hline
\end{tabular}

Table 2. Comparison of mean rarefied richness, abundance and Shannon diversity of the sites P5 (Sapucaia) and P6 (Canoas) affected by the 2006 fish kills with the unaffected sites P4 (Parobé) and P5 (São Leopoldo). Unrarefied richness values are given for additional information.

\begin{tabular}{|c|c|c|c|c|}
\hline & & $\begin{array}{l}\text { Affected Sites } \\
\text { (P5 + P6) }\end{array}$ & & $\begin{array}{l}\text { Unaffected Sites } \\
\text { (P4 + P5) }\end{array}$ \\
\hline Rarefied & mean & 20.0 & & 22.0 \\
\hline \multirow{4}{*}{ Richness } & s.d. & 2.6 & & 5.0 \\
\hline & $\mathrm{t}$-value & & -0.093 & \\
\hline & $\mathrm{p}$ & & 0.337 & \\
\hline & d.f. & & 10.6 & \\
\hline \multirow[t]{2}{*}{ Richness } & mean & 26.6 & & 25.6 \\
\hline & s.d. & 5.5 & & 5.3 \\
\hline \multirow[t]{5}{*}{ Abundance } & mean & 587.4 & & 326.9 \\
\hline & s.d & 379.6 & & 161.0 \\
\hline & $\mathrm{t}$-value & & 1.787 & \\
\hline & $\mathrm{p}$ & & 0.096 & \\
\hline & d.f. & & 14.0 & \\
\hline Shannon & mean & 2.22 & & 2.24 \\
\hline \multirow[t]{4}{*}{ Diversity } & s.d. & 0.3 & & 0.4 \\
\hline & $t$-value & & -0.104 & \\
\hline & $\mathrm{p}$ & & 0.919 & \\
\hline & d.f. & & 14.0 & \\
\hline
\end{tabular}

considerable species diversity. However, rarefied richness is lowest and Shannon diversity second lowest in the most impacted lowland site of São Leopoldo. It appears likely that during the 10 -years period between the first and the second collections the fish fauna is resistant to various anthropogenic influences that affected the river or on the way to recovery.

The observed differences in tested community parameters were relatively small. The analysis of species constancy confirms the stability of the pattern. $\mathrm{R}^{2}$ values for the sites Fraga and Caraá show that stability is more pronounced at the less impacted headwater sites. At the lowland site São Leopoldo species rank correlations of the 1998/00 and $2007 / 09$ collections were not significant. At this sites most species which were abundant in 1998/99 still were abundant
10 years later but their relative abundance changed. C. voga, the most abundant species in $1998 / 99$ with $31.1 \%$, dropped to $8 \%$ in $2007 / 09$. A fasciatus, with $10.6 \%$ in $1998 / 99$, increased to $35.9 \%$. The predator Oligosarcus robustus (Menezes, 1969) decreased from $16.4 \%$ to $1.5 \%$, and H. luetkenii increased from $4 \%$ to $13.9 \%$. It is not clear if these changes indicate long-term patterns of the food web or if they represent erratic changes in abundance.

In the 1998/99 study, 63 species were recorded at five sampling sites (Petry and Schulz, 2006). At the six sampling points of the current study, we identified 68 species, which is similar to what was registered almost ten years ago. The similarity dendrogram reinforces the view of general stability, since it joins the sample sites of the 1998/99 and $2007 / 09$ study in the same clusters. Our results cannot 
estimate diversity change in relation to pre-disturbance conditions, because the composition of the undisturbed community is not known. Most probably the collective community properties decreased with the industrial and domestic sewage discharges in the decade of the 70 s of the last century and the stabilised on a lower level. Schlosser (1990) observed that maximum longevity, maximum body size and age at maturity of fish species are associated with stream order. Higher stream orders tended to have larger and longer-lived fish species which mature at higher ages. In the Sinos River basin three longer-lived species occur, particularly in the higher order lowland sections: the freshwater dourado, Salminus brasiliensis (Cuvier, 1816), piava, Leporinus obtusidens (Valenciennes, 1837), and grumatã, Prochilodus lineatus (Valenciennes, 1837). According to fishermen all of them suffered population declines at the beginning of industrial and municipal pollution from about 1970 on. They appeared in very low abundances in 1998/99 and 2007/09 studies. The long-term pressure disturbances caused by sewage discharges probably caused the decline of these more K-selected species. The decrease of the large O. robustus in favour of small sized H. luetkenii at the São Leopoldo site may be seen as an indicator of this pattern. In the 2007/09 study the piava and grumatã were captured at the lowermost site Canoas (P6), which is located near the Jacuí river delta, a relatively undisturbed refuge or source area. At all other sites these species were absent or occurred in very low abundances. One dourado was captured at the headwater site Caraá. An adipose fin-clip identified the origin of this individual being from a restocking experiment. It seems that after the initial population decline of the most sensitive species a new stable state of the fish community of the Sinos River can be observed, although high sewage discharges and hypoxic conditions still continue.

The comparison of the sites affected by the 2006 pulse disturbance with the unaffected sites showed no significant differences in richness, abundance and Shannon diversity. One year after the fish kills three highly opportunistic species, A.fasciatus, A. jacuiensis and C. voga dominated the community with $51 \%$ to the total abundance at the affected sites. In the adjacent unaffected upstream reach they contributed only with $36 \%$. These small sized species have high environmental plasticity and predominantly omnivorous or detrivorous feeding habits (Graciolli et al., 2003). Detenbeck et al. (1992) reviewed case histories of 49 sites and data on 411 recovery end points. They showed that collective community properties like species composition, richness and total density recovered within one year in $70 \%$ of the systems investigated. Recovery was enhanced by the presence of refuge or source areas. In the case of the affected sites in the Sinos River the adjacent delta of the Jacuí river in downstream direction and the unaffected upstream sites are possible source areas for recolonisation.

Meffe and Sheldon (1990) proposed that recolonisation can be the result of seasonal long range movements, accumulative short range movements, agonistic interactions in the source areas resulting in displacements to the new habitats, larval drift or in situ reproduction. The recolonisation process in the river reaches affected by the 2006 fish kill was not the result of in situ reproduction or larval drift, since one year after the fish kill most captured individuals were adults. Most probably the process was based on short or long range movements, favoured by the proximity of the relatively undisturbed Jacuí delta, which hosts source populations of $A$. fasciatus, A. jacuiensis, C. voga (Marques et al., 2007; Milani and Fontoura, 2007), and even more sensitive species like $P$. lineatus and L. obtusidens (Koch et al., 2000). The latter species are long distance migrators (Zaniboni-Filho and Schulz, 2003) and the others may perform short distance displacements. The resilience of the community affected by the fish kills and the observed stability of the fish community since the 1998/99 study are favoured by the relative integrity of morphological habitat structures. The Sinos River main stem is not channelled, no dams obstruct dispersal, movements and migrations and the lateral connectivity with floodplain structures like oxbows and wetlands is still functional. Aarts et al. (2004) observed that European fish communities are recovering very slowly from chemical pollution, because physical habitat structures are degraded in most rivers. The current Brazilian government projects the construction of sewage treatment plants in every municipality of the Sinos watershed. On the long-term these investments will increase water quality and may favour a fish community with a composition close to pre-disturbance conditions. A precondition for this positive perspective is the conservation of the morphological habitat integrity, which today is becoming under hard pressure.

\section{Conclusions}

1. The probable initial shift of the Sinos fish community from pre-disturbance conditions to permanent high pressure disturbance caused by chemical and organic sewage in the second half of the last century could not be documented by this study. But the comparison of 1998/99 and 2007/09 collection shows that during the period subsequent to a probable initial decline the Sinos fish community remains stable or is on the way to recovery.

2. Recolonisation of the river reach affected by the 2006 fish kill occurred within one year, mostly by opportunistic species through immigration from nearby source and refuge areas.

3. Resilience of the river reaches affected by the 2006 fish kill and the current stability of the communities at the other sampling sites is favoured by the still existing morphological habitat integrity.

4. At the moment river management focuses the increase of water quality by the construction of sewage treatment plants. These efforts should be accompanied by the conservation of the physical habitat structures. 


\section{Acknowledgements}

We would like to thank the staff of the Fish Ecology Laboratory of the Universidade do Vale do Rio dos Sinos - UNISINOS - for their help in the field work, Dr. Volney Vono from UFMG and Cristina Stenert from UNISINOS for various fruitful comments on data analysis. Particularly grateful we are to two unknown referees who invested much time in a very thorough revision of a former version and made a lot of constructive comments.

\section{References}

AARTS, BGW., VAN DEN BRINK, FWB. and NIENHUIS, PH., 2004. Habitat loss as the main cause of the slow recovery of fish faunas of regulated large rivers in Europe: the transversal floodplain gradient. River Research and Applications, vol. 20, no. 1, p. 3-23. http://dx.doi.org/10.1002/rra.720.

AUSTIN, B., 1998. The effects of pollution on fish health. Journal of Applied Microbiology, vol. 85, supplement 1, p. 234S-242S. http:// dx.doi.org/10.1111/j.1365-2672.1998.tb05303.x. PMid:21182713.

BARRELLA, W. and PETRERE, JRM., 2003. Fish community alterations due to pollution and damming in Tietê and Paranapanema Rivers (Brazil). River Research and Applications, vol. 19, no. 1, p. 59-76. http://dx.doi.org/10.1002/rra.697.

BENDER, EA., CASE, TJ. and GILPIN, ME., 1984. Perturbation experiments in community ecology: theory and practice. Ecology, vol. 65 , no. 1, p. 1-13. http://dx.doi.org/10.2307/1939452.

BLUME, KK., MACEDO, JC., MENEGUZZI, A., SILVA, LB., QUEVEDO, DM. and RODRIGUES, MAS., 2010. Water quality assessment of the Sinos River, Southern Brazil. Brazilian Journal of Biology $=$ Revista Brasileira de Biologia, vol. 70, no. 4, supplement, p. 1185-1193. http://dx.doi.org/10.1590/S151969842010000600008. PMid:21225160.

Brasil. Conselho Nacional do Meio Ambiente - CONAMA, 2005. Resolução 357, de 17 de março de 2005. Dispõe sobre a classificação dos corpos de água e diretrizes ambientais para o seu enquadramento, bem como estabelece as condições e padrões de lançamento de efluentes, e dá outras providências. Diário Oficial da União, Brasília, 18 mar., p. 58-63. Available from: www.mma.gov.br/port/conama/res/res05/res35705.pdf. Access in: 05 May, 2013.

CLARKE, KR. and WARWICK, RW., 1994. Change in marine communities: an approach to statistical analysis and interpretation. Plymouth: Plymouth Marine Laboratory. 859 p.

DETENBECK, NE., DEVORE, PH., NIEMI, GJ. and LIMA, A., 1992. Recovery of temperate-stream fish communities from disturbance: a review of case studies and synthesis of theory. Environmental Management, vol. 16, no. 1, p. 33-53. http:// dx.doi.org/10.1007/BF02393907.

DIAZ, RJ. and ROSENBERG, R., 1995. Marine benthic hypoxia: a review of its ecological effects and the behavior responses of benthic microfauna. Oceanography and Marine Biology - an Annual Review, vol. 33, p. 245-303.

FIGUEIREDO, JAS., DRUMM, E., RODRIGUES, MAS. and SPILKI, FR., 2010. The Rio dos Sinos watershed: an economic and social space and its interface with environmental status. Brazilian Journal of Biology $=$ Revista Brasileira de Biologia, vol. 70, no. 4, supplement, p. 1131-1136. PMid:21225153.
GRACIOLLI, G., AZEVEDO, MA. and MELO, FAG., 2003. Comparative study of the diet of Glandulocaudinae and Tetragonopterinae (Ostariophysi: Characidae) in a small stream in Southern Brazil. Studies on Neotropical Fauna and Environment, vol. 38, no. 2, p. 95-103. http://dx.doi.org/10.1076/ snfe.38.2.95.15932.

HAMMER, Ø., HARPER, DAT. and RYAN, PD., 2003. PASTPAlaeontological Statistics. Software version 2.12.

Internacional Business Machina-IBM, 2012. IBM SPSS Statistics. Software version 21

KARIM, MDR., SEKINE, M., HIGUCHI, T., IMAI, T. and UKITA, M., 2003. Simulation of fish behavior and mortality in hypoxic water in an enclosed bay. Ecological Modelling, vol. 159, no. 1, p. 27-42. http://dx.doi.org/10.1016/S0304-3800(02)00282-X.

KOCH, WR., MILANI, PC. and GROSSER, MK., 2000. Guia illustrado peixes - parque do Delta do Jacuí. Porto Alegre: FZB. 96 p.

KREBS, CH., 1998. Ecological methodology. Menlo Park, California: Addison Wesley Longman. 620 p.

LIMA-JUNIOR, SE., CARDONE, IB. and GOITEIN, R., 2006. Fish assemblage structure and aquatic pollution in a Brazilian stream: some limitations of diversity indices and models for environmental impact studies. Ecology of Freshwater Fish, vol. 15 , no. 3, p. 284-290.

MACKEY, RL. and CURRIE, DJ., 2000. A re-examination of the expected effects of disturbance on diversity. Oikos, vol. 88, no. 3, p. 483-493. http://dx.doi.org/10.1034/j.1600-0706.2000.880303.x.

MAGURRAN, AE. and PHILLIP, AT., 2001. Implications of species loss in freshwater fish assemblages. Ecography, vol. 24, no. 6, p. 645-650. http://dx.doi.org/10.1034/j.1600-0587.2001.240603.x.

MARQUES, CS., BRAUN, AS. and FONTOURA, NF., 2007. Estimativa de tamanho de primeira maturação a partir de dados de IGS: Oligosarcus jenynsii, Oligosarcus robustus, Hoplias malabaricus, Cyphocharax voga, Astyanax fasciatus (Characiformes), Parapimelodus nigribarbis, Pimelodus maculatus, Trachelyopterus lucenai, Hoplosternum littorale, Loricariichthys anus (Siluriformes) e Pachyurus bonariensis (Perciformes) no lago Guaíba e Laguna dos Patos, RS. Biociências (Porto Alegre). In Resumos do XVII Encontro Brasileiro de Ictiologia, 2007. Itajaí. Itajaí: Universidade do Vale do Itajaí. p. 137-137.

MEFFE, GK. and SHELDON, AL., 1990. Post-defaunation recovery of fish assemblages in southeastern blackwater streams. Ecology, vol. 71, no. 2, p. 657-667. http://dx.doi.org/10.2307/1940320.

MILANI, PCC. and FONTOURA, NF., 2007. Diagnóstico da pesca artesanal na Lagoa do Casamento, sistema nordeste da Laguna dos Patos: uma proposta de manejo. Biociências, vol. 15 , no. 1 , p. $82-125$.

MORENO, JA., 1961. Clima do Rio Grande do Sul. Porto Alegre: Secretaria da Agricultura. $42 \mathrm{p}$.

NAIME, R. and FAGUNDES, RS, 2005. Controle da qualidade da água do Arroio Portão, RS. Pesquisas em Geociencias, vol. 32 , no. 1 , p. 27-35.

PETRY, AC. and SCHULZ, UH., 2001. Levantamento da comunidade de Peixes do Rio dos Sinos, RS. Acta Biologica Leopoldensia, vol. 23, no. 1, p. 49-58.

PETRY, AC. and SCHULZ, UH., 2006. Longitudinal changes and indicator species of the fish fauna in the subtropical Sinos River, 
Brazil. Journal of Fish Biology, vol. 69, no. 1, p. 272-290. http:// dx.doi.org/10.1111/j.1095-8649.2006.01110.x.

PIHL, L., BADEN, SP. and DIAZ, RJ., 1991. Effects of periodic hypoxia on distribution of demersal fish and crustaceans. Marine Biology, vol. 108, no. 3, p. 349-360. http://dx.doi.org/10.1007/ BF01313644.

PINTO-COELHO, RM., 2000. Fundamentos em ecologia. Porto Alegre, Artes Médicas Sul. 252 p.

Rio Grande do Sul. Fundação Estadual de Proteção Ambiental - FEPAM, 1999. Qualidade das águas do Rio dos Sinos. Porto Alegre: FEPAM. 49 p.

Rio Grande do Sul. Fundação Estadual de Proteção Ambiental - FEPAM, 2007. Eventos de mortalidade de peixes - Rio dos Sinos. Porto Alegre, FEPAM. 185 p.

Rio Grande do Sul. Fundação Estadual de Proteção Ambiental FEPAM, 2013. Qualidade ambiental. FEPAM. Available from: $<$ www.fepam.rs.gov.br/qualidade/qualidade_sinos/sinos.asp $>$. Access in: 10 Sep. 2013.

SCHLOSSER, IJ., 1990. Environmental variation, life history attributes, and community structure in stream fishes: Implications for environmental management and assessment. Environmental Management, vol. 14, no. 5, p. 621-628. http://dx.doi.org/10.1007/ BF02394713.
SCHULZ, UH. and MARTINS-JUNIOR, H., 2001. Astyanax fasciatus as bioindicator of water pollution of Rio dos Sinos, RS, Brazil. Brazilian Journal of Biology $=$ Revista Brasileira de Biologia, vol. 61, no. 4, p. 615-622. http://dx.doi.org/10.1590/ S1519-69842001000400010. PMid:12071317.

SCHULZ, UH., NABINGER, V., GOMES, L. and SILVA, DC., 2006. Projeto identificação dos pontos de impacto da bacia hidrográfica do Rio dos Sinos - retirada e devolução da água. Comitesinos. Available from: $<w w w . c o m i t e s i n o s . c o m . b r>$. Access in: 05 May 2013.

SOTO-GALERA, E., DIAZ-PARDO, E., LÓPEZ-LÓPEZ, E. and LYONS, J., 1998. Fish as indicators of environmental quality in the Rio Lerma Basin, Mexico. Aquatic Ecosystem Health \& Management, vol. 1, p. 267-276.

SÖVÉNYI, J. and SZAKOLCZAI, J., 1993. Studies on the toxic and immunosuppressive effects of cadmium on the common carp. Acta Veterinaria Hungarica, vol. 41, no. 3-4, p. 415-426. PMid:8017244.

ZANIBONI-FILHO, E. and SCHULZ, UH., 2003. Migratory fishes of the Uruguay river. In CAROLSFELD, J., HARVEY, B., ROSS, C. and BAER, A. (Eds.). Migratory fishes of South America: biology, fisheries and conservation status. Victoria: World Fisheries Trust. p. 157-198 